\title{
Editorial
}

\section{Emerging Arboviral Diseases}

\author{
Sultana M Hussain ${ }^{1}$, Iftikhar Ahmed ${ }^{2}$, A R M Saifuddin Ekram ${ }^{3}$, M Fazlur Rahman ${ }^{4}$
}

Arboviruses are emerging causes of serious diseases in the areas previously unaffected. Japanese encephalitis virus and West Nile virus are the two virus with a major public health impact. In many parts of Asia, infection with, Japanese encephalitis virus a sister of West Nile virus, is a daily reality. ${ }^{1} \mathrm{JE}$ is now spreading both eastwards to Australia and westwards to Pakistan, whereas WN virus is spreading from a base in Africa and Western Asia into Eastern Europe and North America. ${ }^{2}$ Japanese encephalitis infection has not been recognized in Bangladesh since an outbreak in 1977 near Mymensingh. ${ }^{3}$ But a prospective hospital-based surveillance study started from June 2003 proved that 6\% of the hospitalized patients of encephalitis in northern part of Bangladesh are suffering from JE. ${ }^{4}$

Epidemics of encephalitis were described in Japan from 1871 onwards, and in 1935 Japanese encephalitis virus was first isolated from a fatal case. ${ }^{5}$ West Nile virus was isolated from the blood of a febrile woman in Uganda in $1973 .{ }^{6}$ Both JE and WE virus are small enveloped RNA virus, members of the Flavivirus genus (family Flaviviridae), named after the prototype yellow fever virus (Latin flavus means yellow). The flaviviruses are relatively new viruses, derived from a common ancestor 10-20,000 years ago which rapidly evolved to form new ecological niches. ${ }^{7}$ Both the virus are transmitted in an enzootic cycle between small birds mainly by Culex mosquitoes, though for JE pigs are important amplifying hosts. Humans become infected by mosquitoes coincidentally, but are not part of the natural cycle.

Mosquitoes are unavoidable in rural Asia, and almost everyone is exposed to the virus. Only about 1 in 300 infections results in disease, and there is a wide range of presentations, from a simple febrile illness to a severe meningoencephalitis, as well as a newly recognized polio-like acute flaccid paralysis. ${ }^{8}$ There are estimated 50,000 cases of Japanese encephalitis annually, with 15,000 deaths. In addition to the high mortality, about half the survivors have severe neuropsychiatric squeal, with associated socioeconomic burden.

West Nile virus causes a non-specific febrile illness, or a characteristic fever-arthralgia-rash syndrome, which occurred in large epidemics in Israel in the 1950s and South Africa in the 1970s. Direct invasion of the central nervous system by the virus to cause encephalitis was thought to be rare. The epidemiology of West Nile virus has changed in recent years. Numbers of cases of encephalitis by the viral infection is seen in all areas where the virus is endemic, and during a large outbreak in Romania in 1996, about 400 patients with neurological squeal had the evidence of WN virus infection. ${ }^{9}$ In 1999, West Nile virus reached America for the first time. Then physicians noticed a cluster of patients suffering from St Louis virus infection (the American sister of flaviviruses, causing encephalitis epidemics). But sick birds at the Bronx zoo and crows

1 Project Research Physician, HSID, ICCDDR, B, Mohakhali, Dhaka-1212, Bangladesh.

2 Professor, Department of Microbiology, Rajshahi Medical College, Rajshahi-6000, Bangladesh.

${ }^{3}$ Professor Department of Medicine, Rajshahi Medical College, Rajshahi-6000, Bangladesh.

${ }^{4}$ Professor, Department of Pathology, Rajshahi Medical College, Rajshahi-6000, Bangladesh. 
dropping from the sky suggested something else, ${ }^{10}$ since the local virus do not usually cause the disease in its natural hosts. WN virus was then subsequently isolated from both avian and human cases. ${ }^{11}$ By the time anti-mosquito drug spraying and the arrival of winter reduced the population of Culex mosquitoes.

These recent findings raise important issues about the spread, control, and pathogenesis of arboviral encephalitis. Many theories have been proposed on how West Nile virus reached New York, including illegally imported exotic birds, airplaneborne mosquitoes, European refugees, and even biological terrorism, but infected birds migrating from Israel now seems to be the most likely probability. ${ }^{12}$ However it arrived, surveillance has shown that the virus is now well established in the region. Japanese encephalitis viruses are also thought to be spread by birds, but mosquitoes blown between Pacific islands may contribute too. ${ }^{13}$

Although we can do little to limit the spread of enzootic flaviviruses but we can minimize the number of human cases. Surveillance of mosquitoes, sentinel birds, and dead birds for West Nile virus in America warned of the summer's impending outbreak. Consequently the number of human cases was minimized by advising people to avoid mosquito bites and by implementing measures to reduce the mosquito population, such as removing breeding sites and spraying. Unfortunately such measures are impracticable in Asia because rice fields in which Culex mosquitoes breed are a mainstay of the economy here. There are no vaccines against WN virus yet. An expensive formalin-inactivated and newer live attenuated vaccine against JEV are available, but not for the majority of the people living in endemic regions. ${ }^{14,}{ }^{15}$ The factors determining who will develop neurological disease infected with JEV is critically important. The relative contributions of the human immune response and viral strain differences are currently being investigated.

\section{References}

1. Solomon $\mathrm{T}$, Cardosa $\mathrm{MJ}$; Emerging arboviral encephalitis: BMJ 2000; 321: 1484-1485 (16 December)

2. Mackienzie JS, Chua KB, Daniel PW et al. Emerging Viral disease of South East Asia and The Western Pacific a frier review. Emrg Infect Dis 2001; 7: 497-504.

3. Khan MA, Khan AQ, Dobrzynski L, Joshi GP, Myat A A. Japanese encephalitis focus in Bangladesh. J Trop Med Hyg 1981; 84: 41-4.

4. Surveillance for encephalitis in Bangladesh: preliminary results, Health Sci Bull 2004; 2: 7-11.

5. Solomon T, Dung NM, Kneen R, Gainsborough M, Vaughn DW, Khanh VT. Japanese encephalitis. J Neurol Neurosurg Psychiatry 2000; 68: 405-415.

6. Hubalck Z, Halouzka J. West Nile fever; a reemerging mosquito-Borne viral disease in Europe. Emerg Infect Dis 1999; 5: 643-650.

7. Gould EA. Zanotto MM, Holmes EC. The genetic evolution of flaviviruses. In: Saluzzo JF, Dodet B, eds. Factors in the emergence of arbovirus diseases. Paris: Elsevier, 1997: 51-63.

8. Solomon T, Kneen R, Dung NM, Khanh VC, Thuy TTN, Ha DQ, et al. Poliomyelitis-like illness due to Japanese encephalitis virus. Lancet 1998; 351: 1094-1097.

9. Tsai TF, Propovici F, Carnescu C, Campbell GL, Nedlelcu NI. West Nile encephalitis epidemic in Southeastern Romania. Lancet 1998; 352: 767-771.

10. Anonymous. Outbreak of West Nile-like viral encephalitis: New York, 1999. Morh Mortal Wkly Rep 1999; 48: 845-849.

11. Briese $T$, Jia X-Y, Huang C, Grady LJ, Lipkin WI. Identification of a Kunjin/West Nile-like flavivirus in brains of patients with New York encephalitis. Lancet 1999; 354: 1261-1262.

12. Rappole $\mathrm{JH}$, Derrickson SR, Hubalek Z. Migratory birds and spread of West Nile virus in the Western Hemisphere. Emerg Infect Dis 2000; 6: 319-328.

13. Hanna JN, Ritchie SA, Philips DA, Lee JM, Hills SL, Van der Hurk AF, et al. Japanese encephalitis in north Queensland, Australia, 1988. Med J Australia 1999; 7: 319-328.

14. Hoke $\mathrm{CH}$, Nisalak A, Sangawhipa N, Jatanasen S, Laorakapongse $\mathrm{T}$, Innis $\mathrm{BL}$, et al. Protection against Japanese encephalitis by inactivated vaccines. N Engl J Med 1988; 319:608-614.

15. Hennessy S, Zhengle L, Tsai TF, Strom BL, Chao-Min W, Hui-Lian L, et al. Effectiveness of live-attenuated Japanese encephalitis vaccine (SA 14-14-2): A case control study. Lancet 1996; 347: 1583-1586.

All correspondence to: Dr. A R M Saifuddin Ekram Professor Department of Medicine Rajshahi Medical College, Rajshahi. 